\title{
Transepithelial Bicarbonate Secretion: Lessons from the Pancreas
}

\author{
Hyun Woo Park and Min Goo Lee \\ Department of Pharmacology, Brain Korea 21 Project for Medical Science, Yonsei University College of \\ Medicine, Seoul 120-752, Korea \\ Correspondence: mlee@yuhs.ac
}

\begin{abstract}
Many cystic fibrosis transmembrane conductance regulator (CFTR)-expressing epithelia secrete bicarbonate $\left(\mathrm{HCO}_{3}^{-}\right)$-containing fluids. Recent evidence suggests that defects in epithelial bicarbonate secretion are directly involved in the pathogenesis of cystic fibrosis, in particular by building up hyperviscous mucus in the ductal structures of the lung and pancreas. Pancreatic juice is one of the representative fluids that contain a very high concentration of bicarbonate among bodily fluids that are secreted from CFTR-expressing epithelia. We introduce up-to-date knowledge on the basic principles of transepithelial bicarbonate transport by showing the mechanisms involved in pancreatic bicarbonate secretion. The model of pancreatic bicarbonate secretion described herein may also apply to other exocrine epithelia. As a central regulator of bicarbonate transport at the apical membrane, CFTR plays an essential role in both direct and indirect bicarbonate secretion. The major role of CFTR in bicarbonate secretion would be variable depending on the tissue and cell type. For example, in epithelial cells that produce a low concentration of bicarbonate-containing fluid (up to $80 \mathrm{~mm}$ ), either CFTR-dependent $\mathrm{Cl}^{-} / \mathrm{HCO}_{3}^{-}$exchange or CFTR anion channel with low bicarbonate permeability would be sufficient to generate such fluid. However, in cells that secrete high-bicarbonate-containing fluids, a highly selective CFTR bicarbonate channel activity is required. Therefore, understanding the molecular mechanism of transepithelial bicarbonate transport and the role of CFTR in each specific epithelium will provide therapeutic strategies to recover from epithelial defects induced by hyposecretion of bicarbonate in cystic fibrosis.
\end{abstract}

$\mathrm{E}_{\mathrm{a}}^{\mathrm{p}}$ pithelial cells in respiratory, gastrointestinal, and genitourinary systems secrete bicarbonate $\left(\mathrm{HCO}_{3}^{-}\right)$-containing fluids, which include saliva, pancreatic juice, intestinal fluids, airway surface fluid, and fluids secreted by reproductive organs. Bicarbonate is an essential ingredi- ent in these fluids and plays critical roles. For example, bicarbonate is the biological $\mathrm{pH}$ buffer that guards against toxic intracellular and extracellular fluctuations in $\mathrm{pH}$ (Roos and Boron 1981). Bicarbonate in pancreatic juice and duodenal fluids neutralizes gastric acid and pro-

Editors: John R. Riordan, Richard C. Boucher, and Paul M. Quinton

Additional Perspectives on Cystic Fibrosis available at www.perspectivesinmedicine.org

Copyright (C) 2012 Cold Spring Harbor Laboratory Press; all rights reserved; doi: 10.1101/cshperspect.a009571

Cite this article as Cold Spring Harb Perspect Med 2012;2:a009571 
vides an optimal $\mathrm{pH}$ environment for digestive enzymes to function properly in the duodenum (Lee and Muallem 2008). In addition, as a moderate chaotropic ion, bicarbonate facilitates the solubilization of macromolecules such as mucins (Hatefi and Hanstein 1969). Recent studies suggest that the abnormal bicarbonate secretion observed in cystic fibrosis (CF) leads to altered mucin hydration and solubilization (Quinton 2010), resulting in hyperviscous mucus that blocks ductal structures of the lung and pancreas (Quinton 2001, 2008).

Pancreatic juice is one of the representative fluids that contain a very high concentration of bicarbonate among bodily fluids secreted from exocrine epithelia. At $\mathrm{pH} 7.4$ and 5\% $\mathrm{CO}_{2}$, the bicarbonate equilibrium concentration is $\sim 25 \mathrm{~mm}$ according to the HendersonHasselbalch equation. In humans and several other species, such as dogs, cats, pigs, and guinea pigs, the pancreas is capable of generat-

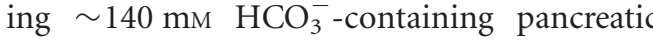
fluid upon stimulation, which is at least a fivefold higher concentration than the plasma. (Domschke et al. 1977; Lee and Muallem 2008). Therefore, pancreatic bicarbonate secretion has attracted attention as a typical model to gain insight into the bicarbonate transport mechanism in diverse epithelial cells. How exocrine glands secrete copious amounts of fluid and bicarbonate has long been a puzzle. The discovery of acidic pancreatic juice from patients with CF was an important advance in understanding the physiological mechanisms of pancreatic bicarbonate secretion (Johansen et al. 1968). In addition, significant progress has been made during the last 25 years with the identification of the molecular nature of many epithelial ion transporters and channels including the cystic fibrosis transmembrane conductance regulator (CFTR), which is mutated in patients with CF (Kerem et al. 1989). We introduce the basic principles of transepithelial bicarbonate transport, in particular in pancreatic duct cells, and the role of CFTR in this process. Additional information on pancreatic bicarbonate secretion can be found in Lee and Muallem (2008) and Lee et al. (2012).

\section{TRANSPORTERS INVOLVED IN TRANSEPITHELIAL BICARBONATE TRANSPORT}

\section{Overview}

Transepithelial bicarbonate secretion is mediated by a coordinated function of transporters in epithelial cells, whereby transporters in the basolateral membrane absorb bicarbonate from the blood and those in the apical membrane secrete bicarbonate to the luminal space of hollow viscus or exocrine ducts. Recent progress in molecular and physiological techniques revealed the molecular identity and function of epithelial ion transporters at the basolateral and apical membranes (Lee et al. 2012). Major discoveries include the identification of anion channels and transporters in the apical membrane, such as CFTR and $\mathrm{Cl}^{-} / \mathrm{HCO}_{3}^{-}$exchangers belonging to the SLC26 family (Ko et al. 2004; Dorwart et al. 2008), in combination with the basolateral bicarbonate uptake mechanisms, such as the $\mathrm{Na}^{+}-\mathrm{HCO}_{3}^{-}$cotransporter (NBC) (Zhao et al. 1994; Lee et al. 2000). This article describes major ion transporters expressed at the basolateral and apical membranes in bicarbonate-secreting epithelial cells and their roles in transepithelial bicarbonate secretion. The basic characteristics of basolateral and apical transporters are illustrated in Figure 1.

\section{Transporters in the Basolateral Membrane}

\section{$\mathrm{Na}^{+} / \mathrm{K}^{+}$ATPase Pump}

The $\mathrm{Na}^{+} / \mathrm{K}^{+}$ATPase pump is expressed in the basolateral membrane of the epithelial cells that actively secrete fluid and electrolytes such as pancreatic duct cells. The $\mathrm{Na}^{+} / \mathrm{K}^{+}$ATPase exchanges three $\mathrm{Na}_{\mathrm{i}}^{+}$for two $\mathrm{K}_{\mathrm{o}}^{+}$with energy generated by ATP hydrolysis (Morth et al. 2011). The $\mathrm{Na}^{+} / \mathrm{K}^{+}$ATPase pump in conjunction with the basolateral $\mathrm{K}^{+}$channels converts the chemical energy of ATP into osmotic energy in the form of the $\mathrm{Na}^{+}$and $\mathrm{K}^{+}$gradients and into electrical energy of a negative membrane potential. These osmotic and electrical energies fuel the fluid and electrolyte transport in epithelial monolayers. The $\mathrm{Na}^{+}$gradient is used for cytosolic 


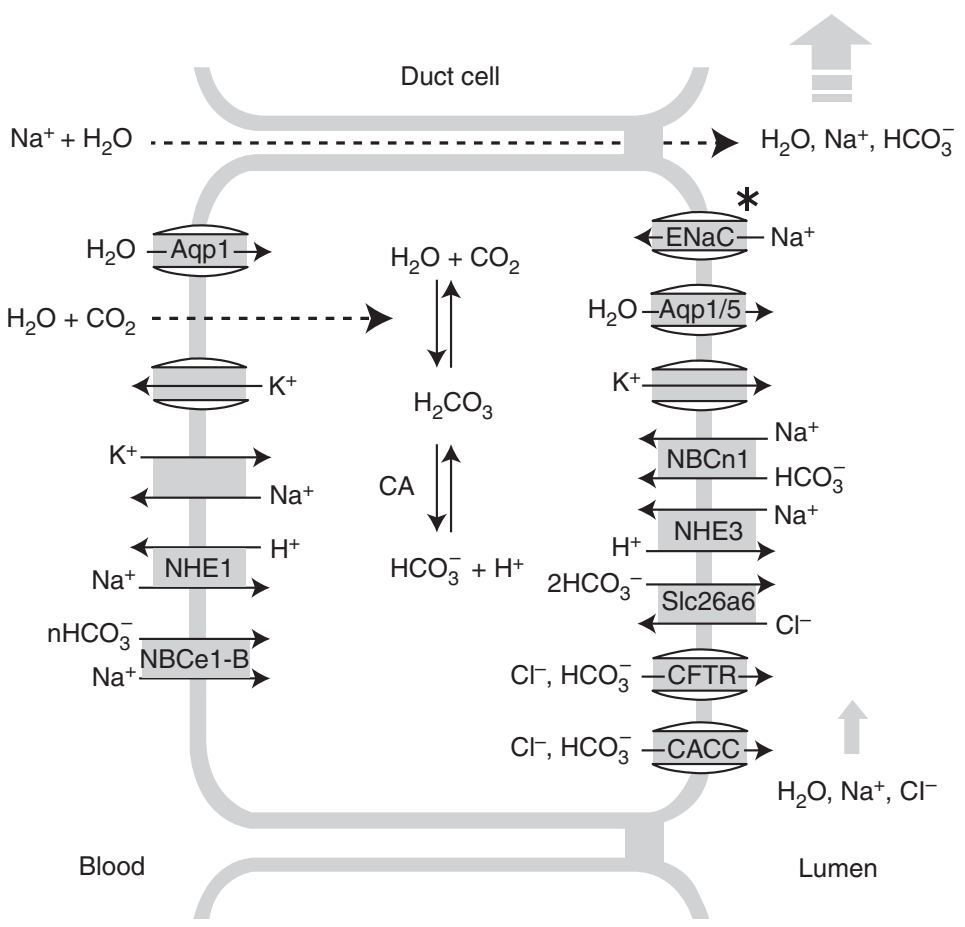

Figure 1. Ion transporters involved in transepithelial bicarbonate transport. Major transporters in the basolateral and luminal membranes of bicarbonate-secreting epithelial cells are illustrated. Bicarbonate uptake through the basolateral membrane is achieved by the NBCe1-B and the combinatorial function of NHE1 and CAs. Apical $\mathrm{HCO}_{3}^{-}$secretion is mostly mediated by the CFTR anion channel and the $\mathrm{Cl}^{-} / \mathrm{HCO}_{3}^{-}$exchanger Slc26a6 in pancreatic duct cells. Some epithelial cells also express (1) bicarbonate-reabsorbing mechanisms such as NHE3 and NBCn1-A; (2) ENaC, which mediates electrogenic $\mathrm{Na}^{+}$absorption; and (3) $\mathrm{K}^{+}$channels that secrete $\mathrm{K}^{+}$to the luminal fluids in the apical membrane. Overall fluid secretion is driven by $\mathrm{HCO}_{3}^{-}$secretion, and $\mathrm{Na}^{+}$and water follow via a paracellular route. Water can also travel through a transcellular route via aquaporins.

bicarbonate accumulation by $\mathrm{Na}^{+}-\mathrm{HCO}_{3}^{-}$cotransporters (NBCs) and $\mathrm{Na}^{+} / \mathrm{H}^{+}$exchangers (NHEs) in the basolateral membrane, and the negative membrane potential facilitates bicarbonate efflux via the electrogenic anion channels and transporters in the apical membrane.

\section{$\mathrm{Na}^{+} / \mathrm{H}^{+}$Exchanger (NHE), V-Type $\mathrm{H}^{+}$ Pump, and $\mathrm{H}^{+} / \mathrm{K}^{+}$ATPase Pump}

Transepithelial bicarbonate secretion requires bicarbonate entry through the basolateral membrane to maintain adequate bicarbonate concentration in the cytoplasm. This can be achieved by the function of $\mathrm{H}^{+}$extrusion mechanisms in the basolateral membrane in conjunction with cytosolic carbonic anhydrases (CAs) that eventually produce bicarbonate from membrane-diffused $\mathrm{CO}_{2}$ and water molecules (Fig. 1). The NHEs are electroneutral $1 \mathrm{Na}^{+} / 1 \mathrm{H}^{+}$ exchangers and exchange $\mathrm{Na}_{\mathrm{o}}^{+}$for $\mathrm{H}_{\mathrm{i}}^{+}$in physiological ion gradients. The mammalian NHE gene family (SLC9A) is composed of three gene clusters: (1) five plasma membrane-type $\mathrm{Na}^{+}$selective NHEs (NHE1-NHE5); (2) four organellar cation nonselective NHEs (NHE6-NHE9); and (3) two distantly related NHE-like genes, termed $\mathrm{Na}^{+} / \mathrm{H}^{+}$antiporter 1 (NHA1) and NHA2 (Lee et al. 2012). The ubiquitous housekeeping NHE1 is essential for $\mathrm{pH}_{\mathrm{i}}$ homeostasis, and it is localized at the basolateral membrane in epithelial cells. Bicarbonate secretion through apical transporters will decrease the bicarbonate concentrations and induce intracellular acidi- 
fication. In acidic $\mathrm{pH}_{\mathrm{i}}$, NHE1 is activated, and it extrudes $\mathrm{H}_{\mathrm{i}}^{+}$in exchange for $\mathrm{Na}_{\mathrm{o}}^{+}$. This, in turn, facilitates the production and accumulation of bicarbonate inside epithelial cells. Similarly, $\mathrm{H}^{+}$extrusion through a vesicular V-type $\mathrm{H}^{+}$-ATPase pump or $\mathrm{H}^{+} / \mathrm{K}^{+}$ATPase pumps at the basolateral membrane can accumulate bicarbonate in epithelial cells. It has been shown that the V-type $\mathrm{H}^{+}$-ATPase pump is expressed in the basolateral membrane of pig pancreatic duct cells (Villanger et al. 1995) and that the gastric and nongastric types of $\mathrm{H}^{+} / \mathrm{K}^{+}$ ATPase pumps are expressed in the basolateral membrane of rat pancreatic duct cells (Novak et al. 2011).

However, the ability of these basolateral $\mathrm{H}^{+}$ extrusion mechanisms to accumulate bicarbonate seems to be limited and does not fully meet the required bicarbonate uptake through the basolateral membrane in cells that secrete high bicarbonate-containing fluids, such as human and guinea pig pancreatic duct cells. For example, NHE1 is activated below a $\mathrm{pH}_{\mathrm{i}}$ of 7.0, indicating that it can retain intracellular bicarbonate concentrations only $\sim 10 \mathrm{~mm}$ at $5 \% \mathrm{CO}_{2}$. In this case, the maximum bicarbonate concentration in pancreatic juice would be only $100 \mathrm{~mm}$ even when the hypothetical bicarbonate channel in the apical membrane is maximally activated (membrane potential at $-60 \mathrm{mV}$ ). Several mathematical models and experimental data suggest that pancreatic duct cells maintain a $20 \mathrm{~mm}$ intracellular bicarbonate concentration $\left(\mathrm{pH}_{\mathrm{i}} 7.3\right)$ that is suitable to generate $>140 \mathrm{~mm}$ bicarbonate-containing fluid (Ishiguro et al. 1996a; Sohma et al. 2000; Whitcomb and Ermentrout 2004). In addition, inhibitors of NHE1 and the V-type $\mathrm{H}^{+}$-ATPase pump produced no or variable effects in reducing pancreatic bicarbonate secretion (Lee and Muallem 2008). Therefore, a more direct bicarbonate uptake mechanism is required in the basolateral membrane of pancreatic duct cells.

\section{$\mathrm{Na}^{+}-\mathrm{HCO}_{3}^{-}$Cotransporter (NBC)}

Evidence suggests that NBC activity at the basolateral membrane is the major route for the basolateral bicarbonate uptake in the pancreatic duct cells (Ishiguro et al. 1996a). The basolateral NBC isoform was cloned from the pancreas and named pNBC1 (Abuladze et al. 1998). Subsequently, pNBC1 was renamed NBCe1-B, which is an electrogenic transporter with 1 $\mathrm{Na}^{+}: 2 \mathrm{HCO}_{3}^{-}$stoichiometry in pancreatic duct cells. The stoichiometry of electrogenic NBC1 (NBCe1) is an important parameter that determines the direction of bicarbonate movement. The stoichiometry of NBCe1 appears to be dependent on the cell type and PKA-dependent phosphorylation status (Gross et al. 2003). For example, the kidney type NBC1 (kNBC1, NBCe1-A), another variant transcribed from the same gene, seems to have $1 \mathrm{Na}^{+}: 3 \mathrm{HCO}_{3}^{-}$ stoichiometry in the basolateral membrane of proximal tubule, where it mediates transepithelial $\mathrm{NaHCO}_{3}$ absorption (hence, outward movement of bicarbonate at the basolateral membrane). In this case, the electrorepulsive force of $3 \mathrm{HCO}_{3}^{-}$overcomes the inward movement of $1 \mathrm{Na}^{+}$molecule. The pancreatic electrogenic NBCe1-B uses the $\mathrm{Na}^{+}$gradient more efficiently to accumulate cytosolic bicarbonate than the electroneutral NHE1, because NBCe1-B transports two bicarbonate molecules into the cells using the electrochemical energy of one $\mathrm{Na}^{+}$ molecule. In fact, it has been shown in guinea pig pancreatic duct cells, that NBCe1-B mediates the bulk of basolateral bicarbonate entry during stimulated secretion (Ishiguro et al. 1996a,b). Recent studies suggested that IRBIT (inositol1,4,5-triphosphate $\left[\mathrm{IP}_{3}\right]$ receptor-binding protein released with $\mathrm{IP}_{3}$ ) is an important regulator of NBCe1-B in pancreas (Shirakabe et al. 2006).

\section{$K^{+}$Channel}

The negative membrane potential generated by $\mathrm{K}^{+}$channels in the basolateral membrane of epithelial cells provides the driving force for $\mathrm{Cl}^{-}$and bicarbonate to exit through the apical membrane, which is a key step that precedes fluid and electrolyte secretion in all secretory epithelial cells. In general, secretory epithelial cells express two important $\mathrm{K}^{+}$channels in the basolateral membrane, a $\mathrm{Ca}^{2+}$ - and voltage-activated $\mathrm{K}^{+}$channel of a large conductance (Maruyama et al. 1983) and a time- and 
voltage-independent $\mathrm{K}^{+}$channel of intermediate conductance (Hayashi et al. 1996; Nehrke et al. 2003). The molecular identity of the channels was subsequently determined as the MaxiK channels encoded by KCNMA1 (Nehrke et al. 2003; Romanenko et al. 2006) and the IK1 channels encoded by KCNN4 (Begenisich et al. 2004; Hayashi et al. 2004), respectively. In the pancreatic duct, MaxiK seems to be the major channel maintaining a negative membrane potential during stimulated bicarbonate secretion (Gray et al. 1990). However, MaxiK channels do not appear to contribute to resting membrane potential, possibly because they have a very low open probability during the unstimulated state. The IK1 channel is a potential basolateral $\mathrm{K}^{+}$ channel responsible for the resting $\mathrm{K}^{+}$permeability (Novak and Greger 1988).

\section{$\mathrm{Na}^{+} / \mathrm{K}^{+} / 2 \mathrm{Cl}^{-}$Cotransporter (NKCC) and $\mathrm{Cl}^{-} / \mathrm{HCO}_{3}^{-}$Exchanger (Anion Exchanger, $\mathrm{AE}$ )}

Epithelial cells that secrete $\mathrm{Cl}^{-}$-rich fluids, such as acinar cells in the exocrine pancreas and salivary glands, express the $\mathrm{Na}^{+} / \mathrm{K}^{+} / 2 \mathrm{Cl}^{-}$cotransporter NKCC1 in the basolateral membrane. Owing to the electroneutrality of its transport process, NKCC1 maintains intracellular $\mathrm{Cl}^{-}$concentrations above the electrochemical equilibrium. This high intracellular $\mathrm{Cl}^{-}$concentration together with the negative membrane potential generated by the basolateral $\mathrm{K}^{+}$channel provides the driving force for fluid and electrolyte secretion to the luminal space when the apical $\mathrm{Cl}^{-}$channel is opened by physiological stimuli. However, as we discuss below, a high intracellular $\mathrm{Cl}^{-}$concentration is unfavorable to secrete a high concentration of bicarbonate via CFTR or $\mathrm{Cl}^{-} / \mathrm{HCO}_{3}^{-}$exchangers at the apical membrane. Therefore, basolateral NKCC is absent in epithelial cells that produce fluids containing an extremely high concentration of bicarbonate, such as human and guinea pig pancreatic duct cells.

The $\mathrm{Cl}^{-} / \mathrm{HCO}_{3}^{-}$exchanger AE2 is found in the basolateral membrane of almost all epithelial cells. AE2 is activated by alkaline $\mathrm{pH}_{\mathrm{i}}$ to extrude excessive cytosolic bases (Olsnes et al. 1986). In physiological ion gradients, the baso- lateral $\mathrm{AE}$ accumulates $\mathrm{Cl}^{-}$inside the cells and dissipates accumulated intracellular bicarbonate. Therefore, although basolateral AE2 is required for a housekeeping function of cells preventing overt intracellular alkalinization, its activation would inhibit apical bicarbonate secretion in epithelial cells. In fact, mathematical models suggest that inhibition of basolateral AE activity is required for the high bicarbonate secretion in pancreatic duct cells (Sohma et al. 1996, 2000; Whitcomb and Ermentrout 2004).

\section{Transporters in the Apical Membrane}

\section{Cystic Fibrosis Transmembrane Conductance Regulator (CFTR)}

CFTR (ABCC7) belongs to the "C" branch of the ATP-binding cassette $(\mathrm{ABC})$ transporter superfamily. Most ABC transporters function as membrane pumps, which transport their substrates against the electrochemical gradient using energy generated from ATP hydrolysis (Deeley et al. 2006). Unlike other ABC transporters, CFTR is an anion channel that permits diffusion of substrate ion molecules down to the preexisting electrochemical gradient. In expression cloning, CFTR functions as a cAMP-activated $\mathrm{Cl}^{-}$channel that has a small conductance (5-10 pS) and a linear current-voltage relationship (Tabcharani et al. 1991).

CFTR is expressed in the apical membrane of secretory epithelial cells. CFTR $\mathrm{Cl}^{-}$channels have a limited permeability to bicarbonate in typical physiologic conditions. At normal intracellular $(>20 \mathrm{~mm})$ and extracellular $(>100 \mathrm{~mm})$ $\mathrm{Cl}^{-}$concentrations, the $\mathrm{P}_{\mathrm{HCO} 3} / \mathrm{P}_{\mathrm{Cl}}$ of CFTR is 0.2-0.5 (Poulsen et al. 1994; Linsdell et al. 1997; Shcheynikov et al. 2004). Importantly, CFTR bicarbonate permeability is dynamically regulated by intracellular $\mathrm{Cl}^{-}$concentration-sensitive kinases (Park et al. 2010). Recently, two related kinase families - with-no-lysine (WNK) kinases and sterile 20 (STE20)-like kinaseshave emerged as osmotic sensors that modulate diverse ion transporters (Anselmo et al. 2006; Richardson and Alessi 2008). In general, osmotic stress such as a decrease in the intracellular $\mathrm{Cl}^{-}$concentration, $\left[\mathrm{Cl}^{-}\right]_{\mathrm{i}}$, activates $\mathrm{WNK}$ 
kinases, including WNK1, which subsequently phosphorylate and activate downstream STE20like kinases, especially oxidative stress-responsive kinase 1 (OSR1) and STE20/SPS1-related proline/alanine-rich kinase (SPAK) (Richardson and Alessi 2008). In pancreatic duct cells, CFTR activation greatly reduces $\left[\mathrm{Cl}^{-}\right]_{\mathrm{i}}$, which triggers the activation of WNK1-SPAK/OSR1 kinase cascade. Activation of the WNK1SPAK/OSR1 pathway results in a dramatic increase in CFTR bicarbonate permeability, making CFTR primarily a bicarbonate-selective channel (Park et al. 2010). A bicarbonate channel forms an electrodiffusive bicarbonate efflux pathway that is essential for the generation of pancreatic juice containing bicarbonate at concentrations exceeding $140 \mathrm{~mm}$.

In addition to $\mathrm{Cl}^{-}$and bicarbonate channel activity, CFTR has been suggested to be a central regulator of fluid and electrolyte secretion in many epithelia by regulating other membrane transporters (Lee et al. 2012). CFTR exists in a macromolecular complex at the apical membrane of secretory epithelia. The carboxyl terminus of CFTR forms a PDZ ligand that binds to PDZ domain-containing scaffolds (Short et al. 1998; Wang et al. 1998). In addition, CFTR interacts with SNARE proteins, AKAPs, kinases, and phosphatases (Guggino 2004). In these complexes, CFTR directly or indirectly regulates the activity of several transporters. Functional interactions with CFTR were reported for epithelial $\mathrm{Na}^{+}$channels (ENaCs), outwardly rectifying $\mathrm{Cl}^{-}$channels, $\mathrm{Ca}^{2+}$-activated $\mathrm{Cl}^{-}$channels, ROMK2 and KvLQT1 $\mathrm{K}^{+}$channels, SLC26 transporters, NHE3, NBCn1-A (NBC3), and aquaporins (AQPs) (Kunzelmann 2001; Lee and Muallem 2008).

\section{$\mathrm{Cl}^{-} / \mathrm{HCO}_{3}^{-}$Exchanger (Anion Exchanger, $\mathrm{AE}$ )}

Many exocrine glands are composed of two types of cells: the acinar cells initially secreting $\mathrm{Cl}^{-}$-rich fluids, and the duct cells modifying the ionic composition of the fluids. Pancreatic duct cells absorb luminal $\mathrm{Cl}^{-}$and secrete the bulk of bicarbonate and fluids. Although the CFTR anion conductive pathway could directly produce bicarbonate-containing fluids, thermodynam- ically, an apical $\mathrm{Cl}^{-} / \mathrm{HCO}_{3}^{-}$exchanger can much more efficiently secrete bicarbonate into the lumen when the luminal space contains $\mathrm{Cl}^{-}$. In fact, it has been proposed that the $\mathrm{Cl}^{-} /$ $\mathrm{HCO}_{3}^{-}$exchanger in the apical membrane mediates bicarbonate secretion in cooperation with an apical $\mathrm{Cl}^{-}$channel in pancreatic ducts (Steward et al. 2005; Lee and Muallem 2008). In this case, apical $\mathrm{Cl}^{-}$channels facilitate bicarbonate secretion by recycling $\mathrm{Cl}^{-}$to the lumen, which maintains the luminal $\mathrm{Cl}^{-}$concentration for continuous apical $\mathrm{Cl}^{-} / \mathrm{HCO}_{3}^{-}$exchange.

The first family of $\mathrm{Cl}^{-} / \mathrm{HCO}_{3}^{-}$exchangers to be considered is members of the solutelinked carrier 4 (SLC4) family (Lee et al. 2012). The pancreatic duct cells express the SLC4 transporter AE2 (SLC4A2), but it is localized on the basolateral membrane (Roussa et al. 1999, 2001). The second type of $\mathrm{Cl}^{-} / \mathrm{HCO}_{3}^{-}$exchangers comprise transporters belonging to the SLC26 transporter family, which consists of 10 members and transports diverse anions, such as chloride, bicarbonate, oxalate, and sulfate (Ohana et al. 2009). Among the members, SLC26A3, SLC26A4, and SLC26A6 function as $\mathrm{Cl}^{-} / \mathrm{HCO}_{3}^{-} / \mathrm{I}^{-}$exchangers (Ko et al. 2002; Xie et al. 2002). Slc26a6 appears to be the major $\mathrm{Cl}^{-} / \mathrm{HCO}_{3}^{-}$exchanger in the apical membrane of rat pancreatic duct cells and has electrogenic 1 $\mathrm{Cl}^{-} / 2 \mathrm{HCO}_{3}^{-}$exchange activity (Wang et al. 2006; Shcheynikov et al. 2008; Stewart et al. 2009). As discussed below, this electrogenicity of SLC26A6 further contributes to the outward transport of bicarbonate at physiological negative membrane potential. An important feature of the SLC26 transporters and CFTR is their mutual regulation. Thus, the STAS domain of SLC26 transporters interacts with the R domain of CFTR. In addition, the two transporters are connected by PDZ-based adaptors. These interactions are required for activation of both the SLC26 transporters and CFTR (Ko et al. 2004).

\section{$\mathrm{Ca}^{2+}$-Activated $\mathrm{Cl}^{-}$Channel (CaCC)}

$\mathrm{CaCC}$ activity is present in the apical membrane of almost all secretory epithelial cells (Gray et al. 1989, 1994; Zeng et al. 1997; Venglovecz et al. 2008). The biophysical property of the channel 
has been characterized to be a voltage- and $\mathrm{Ca}^{2+}$-activated, time-dependent outwardly rectifying channel (Melvin et al. 2005; Kunzelmann et al. 2009). Recently, members of the anoctamin (ANO; also known as TMEM16) family, in particular ANO1/TMEM16A and ANO2/TMEM16B, were shown to function as CaCCs in several epithelial and neuronal tissues (Caputo et al. 2008; Schroeder et al. 2008; Yang et al. 2008; Stephan et al. 2009; Romanenko et al. 2010). ANO1 is expressed at high levels in the apical membranes of salivary glands (Schroeder et al. 2008; Yang et al. 2008) and pancreatic acinar cells (Huang et al. 2009). However, the molecular identity of $\mathrm{CaCC}$ in the pancreatic duct cell is still unknown. The discovery of the ANO/ TMEM16 family as the CaCC in several epithelial cells suggests that the ductal CaCC is likely a member of this family. Whether the other ANO/TMEM16 isoforms mediate CaCC activity in pancreatic duct cells awaits further studies (Lee et al. 2012). An interesting possibility is that $\mathrm{CaCCs}$ may replace the anion channel function of CFTR in bicarbonate secretion (Zsembery et al. 2000). The $\mathrm{P}_{\mathrm{HCO} 3} / \mathrm{P}_{\mathrm{Cl}}$ of heterologously expressed ANO1 is $0.1-0.5$, indicating that CaCC has a limited ability to produce bicarbonate secretion at typical physiological conditions. However, the $\mathrm{P}_{\mathrm{HCO} 3} / \mathrm{P}_{\mathrm{Cl}}$ of ANO1 seems to be dynamically regulated by $\left[\mathrm{Ca}^{2+}\right]_{\mathrm{i}}$ (MG Lee, unpubl.), suggesting that $\mathrm{CaCC}$ may play a role in epithelial bicarbonate secretion under certain specific conditions.

\section{$K^{+}$Channel}

Some secretory epithelial cells secrete $\mathrm{K}^{+}$into the lumen. For example, the salivary gland duct cells absorb $\mathrm{Na}^{+}$and secrete $\mathrm{K}^{+}$into salivary fluid. Deletion of Kcnmal, which encodes MaxiK, impairs salivary $\mathrm{K}^{+}$secretion, suggesting MaxiK to be the channel responsible for $\mathrm{K}^{+}$ efflux in salivary glands (Nakamoto et al. 2008). A recent study showed that MaxiK channels are also expressed at the apical membrane of pancreatic duct cells in guinea pigs (Venglovecz et al. 2011), which may contribute to the potentiation of secretin and CCK (or other $\mathrm{Ca}^{2+}$ agonists such as cholinergic) response in pancre- atic secretion (Gray et al. 1990). However, the physiological role of the apical $\mathrm{K}^{+}$channel in pancreatic duct cells is not fully understood at present, because unlike saliva, the major cation in pancreatic juice is $\mathrm{Na}^{+}$and pancreatic duct cells do not secrete the bulk of $\mathrm{K}^{+}$.

\section{Epithelial $\mathrm{Na}^{+}$Channel (ENaC)}

Some surface epithelial cells of respiratory and digestive tracts and duct cells of salivary glands express $\mathrm{ENaC}$ at the apical membrane, which mediates electrogenic $\mathrm{Na}^{+}$uptake in these cells (Cook et al. 2002; Catalan et al. 2010). However, pancreatic duct cells do not express $\mathrm{ENaC}$, because they do not absorb $\mathrm{Na}^{+}$. Simple absorption of $\mathrm{Na}^{+}$without secreting $\mathrm{K}^{+}$is unfavorable for bicarbonate and fluid secretion because it will evoke a lumen-negative transepithelial potential and net fluid absorption. In the lungs, CFTR is proposed to inhibit $\mathrm{ENaC}$ channel function, and deletion of CFTR increases $\mathrm{ENaC}$ activity and fluid absorption, which causes a contraction in airway surface fluids (Berdiev et al. 2009). However, in salivary glands, deletion of CFTR inhibited $\mathrm{Na}^{+}$absorption by $\mathrm{ENaC}$ and greatly diminished the expression of $\alpha$-ENaC (Catalan et al. 2010). Similarly, ENaC activity is markedly reduced in the sweat ducts of CF patients (Reddy et al. 1999). It is not known whether these tissue-specific regulations of $\mathrm{ENaC}$ by CFTR affect transepithelial bicarbonate secretion in $\mathrm{ENaC}$-expressing epithelial cells.

\section{NHE and NBC}

Many $\mathrm{Na}^{+}$- and fluid-absorbing epithelial cells express NHE in the apical membrane, which mediates electroneutral $\mathrm{Na}^{+}$uptake (Cook et al. 2002; Catalan et al. 2010). NHE2 and NHE3 are the major NHE isotypes expressed in the apical membrane of epithelial cells. NHE activity in the apical membrane will nullify bicarbonate secretion by donating protons to the lumen. Interestingly, NHEs are expressed in the apical membrane of cells in the distal parts of large-sized salivary and pancreatic ducts, and they may reabsorb bicarbonate when bicarbonate secretion is not needed in these cells (Marteau et al. 1995; 
H.W. Park and M.G. Lee

Park et al. 1999; Lee et al. 2000; Luo et al. 2001; Bobulescu et al. 2005). At resting state or low flow rates, pancreatic juice is acidic and contains a high amount of $\mathrm{CO}_{2}$, indicating an active $\mathrm{H}^{+}$ secretion by the apical transporters (Gerolami et al. 1989; Marteau et al. 1993). This seems to be mainly mediated by NHE3 in the large-sized ducts (Ahn et al. 2001). The salivary and pancreatic ducts also express the electroneutral NBCn1-A (NBC3) in the apical membrane (Park et al. 2002), which absorbs $\mathrm{Na}^{+}$and bicarbonate from luminal fluids. Similar to the case of NHE3, NBCn1-A appears to have a bicarbonate-salvaging function in the resting state (Park et al. 2002).

\section{Other Factors}

\section{Aquaporin (AQP)}

Transcellular ion secretion results in osmotic water flow. Although the membrane lipid bilayer and paracellular junctions are partially permeable to water, transepithelial water flow is facilitated by the water channel AQP. The AQP family consists of 13 members, all of which can function as water channels, but some can transport additional molecules such as glycerol, urea, ions, and $\mathrm{CO}_{2}$ (Verkman 2008). In epithelia, the AQPs show highly restricted and cell-specific expression patterns. For example, AQP1 is expressed in both the apical and basolateral domains (Burghardt et al. 2003), whereas AQP5 is expressed in the apical membrane of salivary gland and pancreatic duct cells (Delporte and Steinfeld 2006).

\section{Carbonic Anydrase (CA)}

CAs comprise a class of proteins essential for all bicarbonate-related transport functions. The global CA inhibitor acetazolamide significantly inhibits pancreatic fluid and bicarbonate secretion (Pak et al. 1966; Dyck et al. 1972). Further studies revealed that CAs are present at the bicarbonate transporting complex to facilitate bicarbonate transport via membrane transporters, such as NBCs and SLC26 transporters (McMurtrie et al. 2004).

\section{PDZ-Based Adaptor}

Transepithelial bicarbonate transport is achieved by the cooperative operation of several membrane proteins in the basolateral and apical membranes. A mechanism that enhances the efficiency of this close cooperation is protein complex formation by adaptor proteins containing PDZ domains (Fig. 2). The PDZ domain was identified as a conserved domain in three proteins: PSD-95, Discs-large, and ZO-1. The PDZ domain is a protein-protein interaction module consisting of 80-90 amino acids that typically binds to target proteins harboring specific carboxy-terminal sequences called PDZ-binding motifs. Although they were initially identified in neuronal tissues, subsequent studies revealed that PDZ-based adaptor proteins are also expressed in diverse epithelia and play critical roles in transepithelial fluid and electrolyte transport (Gee et al. 2009).

The most well-known PDZ-based adaptors in epithelia are the $\mathrm{Na}^{+} / \mathrm{H}^{+}$exchanger regulatory factor (NHERF) proteins. NHERF1 (EBP50), NHERF2 (E3KARP), and NHERF3 (CAP70, PDZK1) facilitate the PKA-dependent phosphorylation and membrane trafficking of CFTR and NHE3 in epithelial cells of respiratory and digestive systems, including pancreatic duct cells. These adaptors assemble a large protein complex in the apical membrane of secretory epithelia, where CFTR functions as a central regulator. For example, the mutual regulation of CFTR and SLC26 transporters is enhanced by protein-protein interactions through PDZ-based scaffolds (Ko et al. 2002). In addition, the apical NHE3 and NBCn1-A are associated with CFTR via PDZ-based adaptors, such as NHERF1 and NHERF2, and their activity is regulated by CFTR in the protein complex (Ahn et al. 2001; Park et al. 2002). Assembling a large protein complex greatly enhances signaling efficiency in confined regions of the apical membrane. Upon stimulation with cAMP, bicarbonate-secreting transporters, such as CFTR and apical $\mathrm{Cl}^{-} / \mathrm{HCO}_{3}^{-}$ exchangers, are activated, and at the same time, bicarbonate-absorbing transporters, such as NHE3 and NBCn1-A, are inhibited to efficiently 


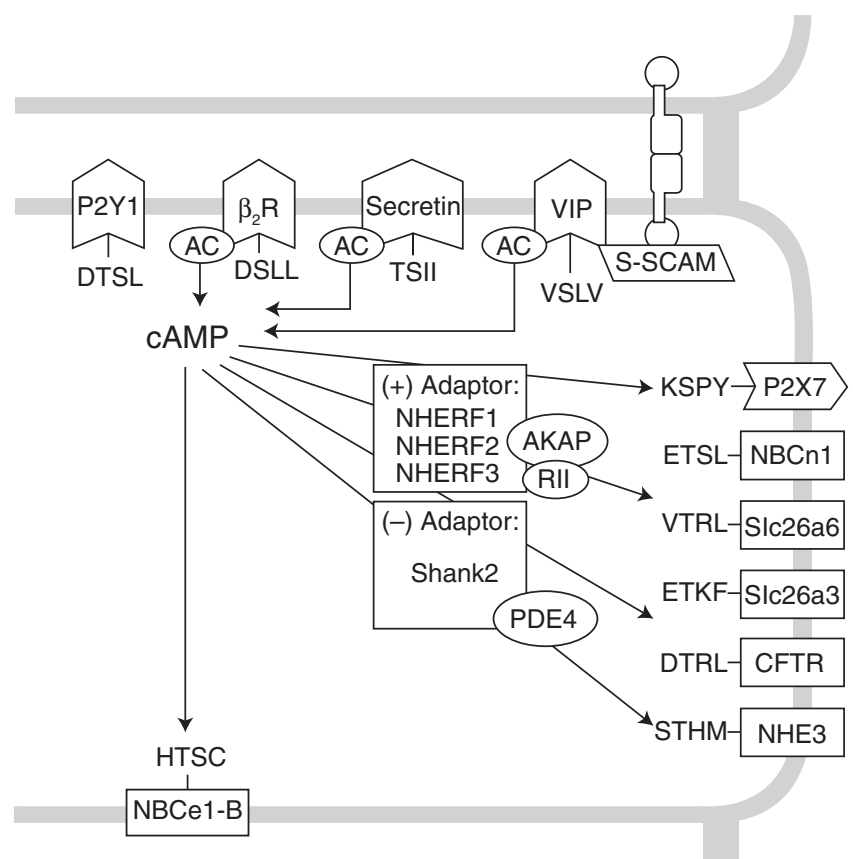

Figure 2. PDZ-based protein-protein interaction in bicarbonate-transporting epithelia. Many membrane receptors and transporters participating in the bicarbonate homeostasis in epithelial cells have a PDZ-binding motif (-X-T/S-X-hydrophobic amino acid) on their carboxyl terminus. The carboxy-terminal sequences are based on the human clones. Excluding purinergic receptors, most of the proteins are associated with cAMPdependent processes. AC, Adenylyl cyclase; AKAP, cAMP-dependent protein kinase-anchoring protein; P2, purinergic receptor; RII, regulatory subunit of protein kinase A type II. (Other abbreviations are the same as described in the text.)

mediate bicarbonate and fluid secretion (Lee et al. 2012).

In addition to the NHERFs, several other scaffolds with PDZ domains, such as Shank2, S-SCAM, SAP97, and PSD-95, are expressed in various epithelial cells and participate in the regulation of transepithelial fluid and ion transport (Kim et al. 2004; Gee et al. 2009). For example, Shank2 is expressed at the apical region of transporting epithelial cells and modulates the activity of CFTR and NHE3 (Kim et al. 2004; Han et al. 2006). In contrast with NHERF proteins that deliver cAMP/PKA signals, Shank2 mediates an inhibitory effect on the cAMP/ PKA pathway. Shank2 associates with phosphodiesterase 4D, which hydrolyzes cAMP, hence lowering local cAMP concentrations in the apical microdomains (Lee et al. 2007). Therefore, the activity ofCFTR is dynamically regulated by a competitive balance between CFTR-activating
(NHERFs) and CFTR-inactivating (Shank2) PDZ-domain interactions (Lee et al. 2012).

Many G-protein-coupled receptors (GPCRs) in epithelial cells also have PDZ ligands at their carboxyl termini (Fig. 2). This recruits the GPCRs to the transporting complex, resulting in polarized GPCR expression and delivery of the second messengers to the specific intracellular microdomains. A good example for such an arrangement is the vasoactive intestinal polypeptide (VIP) receptor $\mathrm{VPAC}_{1}$, which binds to the PDZ-based scaffold S-SCAM (Gee et al. 2009). S-SCAM associates with E-cadherin, a key protein at the adherens junction, and recruits $\mathrm{VPAC}_{1}$ to the junctional area near the apical pole. Confined localization of $\mathrm{VPAC}_{1}$ at the junctional area generates a localized cAMP signal close to the apical effectors such as CFTR. This, in turn, enables efficient bicarbonate and fluid secretion in epithelial cells in response to 
H.W. Park and M.G. Lee

VIP with minimal effects on the cell interior (Gee et al. 2009; Lee et al. 2012).

\section{MODEL FOR PANCREATIC BICARBONATE SECRETION}

Studies on the mechanism and regulation of epithelial bicarbonate secretion have been concentrated in the pancreatic ducts, because the pancreatic duct epithelial cells secrete copious amounts of bicarbonate. Argent and Case (1994) proposed the first model to explain pancreatic bicarbonate secretion. In this model, basolateral NHE1 in cooperation with cytosolic CAs provides a bicarbonate entry mechanism. Bicarbonate is then secreted by $\mathrm{Cl}^{-} / \mathrm{HCO}_{3}^{-}$exchange at the apical membrane. During this process, the apical $\mathrm{Cl}^{-} / \mathrm{HCO}_{3}^{-}$exchange absorbs the $\mathrm{Cl}^{-}$, which is then recycled by exiting through CFTR (Argent and Case 1994; Steward et al.2005). Subsequently, this model was revised by several major findings. For example, the major basolateral bicarbonate influx mechanism was identified as NBCe1-B, which functions as a $1 \mathrm{Na}^{+} / 2 \mathrm{HCO}_{3}^{-}$cotransporter (Zhao et al. 1994; Ishiguro et al. 1996a; Abuladze et al. 1998). In addition, studies in perfused guinea pig pancreatic ducts and mathematical modeling suggested that a bicarbonate channel activity is required to set the final bicarbonate concentration in the pancreatic juice to $140 \mathrm{~mm}$ (Sohma et al. 2000; Whitcomb and Ermentrout 2004).

The pancreatic duct absorbs $\mathrm{Cl}^{-}$and secretes bicarbonate to generate pancreatic juice containing $\sim 20 \mathrm{mM} \mathrm{Cl}^{-}$and $140 \mathrm{~mm} \mathrm{HCO}_{3}^{-}$. The loss of pancreatic bicarbonate secretion in patients with CF (Johansen et al. 1968) indicates that CFTR plays a critical role in bicarbonate secretion. Interestingly, the activity of the apical $\mathrm{Cl}^{-} / \mathrm{HCO}_{3}^{-}$exchanger is dependent on the expression of CFTR (Lee et al. 1999a,b). These results strengthened the idea that $\mathrm{Cl}^{-} /$ $\mathrm{HCO}_{3}^{-}$exchange mediates pancreatic bicarbonate secretion. However, a limitation of this model has been realized by many people that a classical 1:1 electroneutral $\mathrm{Cl}^{-} / \mathrm{HCO}_{3}^{-}$exchanger is able to secrete only a maximum of $80 \mathrm{~mm}$ $\mathrm{HCO}_{3}^{-}$when intracellular concentrations of $\mathrm{Cl}^{-}$and bicarbonate are estimated to be equal.
In comparison to these electroneutral transporters, electrogenic bicarbonate transporters are capable of secreting higher concentrations of bicarbonate when the electrorepulsive force generated by the negative membrane potential is coupled to the efflux of bicarbonate. Interestingly, recent studies have suggested that the apical $\mathrm{Cl}^{-} / \mathrm{HCO}_{3}^{-}$exchangers may be electrogenic with distinct $\mathrm{Cl}^{-}: \mathrm{HCO}_{3}^{-}$stoichiometry (Ko et al. 2004). In case of an electrogenic $1 \mathrm{Cl}^{-} / 2$ $\mathrm{HCO}_{3}^{-}$, it can accumulate greater amounts of bicarbonate in pancreatic juice compared with an electroneutral exchanger (Steward et al. 2005). Nevertheless, this transporter cannot fully account for the bicarbonate-driven fluid secretion in pancreatic duct cells because $\mathrm{a} \mathrm{Cl}^{-} /$ $\mathrm{HCO}_{3}^{-}$exchanger with 1:2 stoichiometry is still insufficient to attain $140 \mathrm{~mm} \mathrm{HCO}_{3}^{-}$in the lumen (Steward et al. 2005). More importantly, the driving force for bicarbonate secretion by the $\mathrm{Cl}^{-} / \mathrm{HCO}_{3}^{-}$exchanger are greatly weakened when the luminal $\mathrm{Cl}^{-}$concentration decreases in the subsequent step of pancreatic secretion, because luminal $\mathrm{Cl}^{-}$must be required for the $\mathrm{Cl}^{-} / \mathrm{HCO}_{3}^{-}$exchanger-mediated bicarbonate secretion. However, it has been shown that a significant fraction of pancreatic bicarbonate secretion is retained even in the absence of luminal $\mathrm{Cl}^{-}$(Ishiguro et al. 1998, 2009). This implies that an unknown mechanism is likely to be responsible for the ductal bicarbonate secretion, especially at the subsequent stage when the bicarbonate concentration mediated by $\mathrm{Cl}^{-} / \mathrm{HCO}_{3}^{-}$exchange approaches equilibrium.

Bicarbonate channels are strong candidates for the transporter responsible for high-concentration bicarbonate secretion (Steward et al. 2005; Lee and Muallem 2008). Having a bicarbonate-selective channel in the apical membrane of a duct cell makes it theoretically possible to secrete up to $200 \mathrm{~mm} \mathrm{HCO}_{3}^{-}$if cells maintain a membrane potential of $-60 \mathrm{mV}$. It has been previously suggested that CFTR functions as a bicarbonate channel in pancreatic duct cells under some specific conditions (O'Reilly et al. 2000; Reddy and Quinton 2003; Shcheynikov et al. 2004; Whitcomb and Ermentrout 2004; Ishiguro et al. 2009). However, the $\mathrm{P}_{\mathrm{HCO} 3} /$ $\mathrm{P}_{\mathrm{Cl}}$ of CFTR was reported to be $\sim 0.2-0.5$ 
(O’Reilly et al. 2000; Sohma et al. 2000). With this permeability ratio, the CFTR anion channel would secrete $\mathrm{Cl}^{-}$much faster than it would secrete bicarbonate. Thus, CFTR is unable to secrete sufficient amounts of bicarbonate when cells retain a significant intracellular concentration of $\mathrm{Cl}^{-}$. In one of the previous models, the basolateral membrane was set to be absolutely impermeable to $\mathrm{Cl}^{-}$but allowed to uptake bicarbonate continuously via basolateral pNBC (Whitcomb and Ermentrout 2004). This caused an extreme reduction in $\left[\mathrm{Cl}^{-}\right]_{\mathrm{i}}$ close to $0 \mathrm{~mm}$ by CFTR activation, which secretes $\mathrm{Cl}^{-}$to the lumen. Under these circumstances, the CFTR anion channel secretes isotonic bicarbonate, because of the absence of $\mathrm{Cl}^{-}$inside the cells. As exemplified in this model, $\left[\mathrm{Cl}^{-}\right]_{\mathrm{i}}$ is a critical parameter that determines the anion composition in fluids secreted by epithelial cells, and a decrease in $\left[\mathrm{Cl}^{-}\right]_{\mathrm{i}}$ can greatly increase bicarbonate secretion via apical anion channels and transporters. In fact, experimental data in guinea pig ducts and human pancreatic duct cells revealed that $\left[\mathrm{Cl}^{-}\right]_{\mathrm{i}}$ in duct cells is $\sim 20 \mathrm{~mm}$ at the resting state, and this level is reduced when CFTR is stimulated with CAMP (Ishiguro et al. 2002; Park et al. 2010). However, the minimum $\left[\mathrm{Cl}^{-}\right]_{\mathrm{i}}$ that can be induced by a maximum cAMP stimulation is $5 \mathrm{~mm}$ in a practical situation, perhaps because of a small $\mathrm{Cl}^{-}$leak via basolateral $\mathrm{Cl}^{-} / \mathrm{HCO}_{3}^{-}$exchangers or $\mathrm{Cl}^{-}$channels. At this $\left[\mathrm{Cl}^{-}\right]_{\mathrm{i}}$, known anion transporters in the apical membrane are still unable to accumulate bicarbonate at concentrations exceeding $140 \mathrm{~mm}$ in pancreatic juice. At $20 \mathrm{~mm}\left[\mathrm{HCO}_{3}^{-}\right]_{\mathrm{i}}$ and $5 \mathrm{~mm}\left[\mathrm{Cl}^{-}\right]_{\mathrm{i}}$, the maximum bicarbonate equilibrium concentration in pancreatic juice that can be attained by the $1 \mathrm{Cl}^{-} / 2 \mathrm{HCO}_{3}^{-}$exchanger is $128 \mathrm{~mm}$ (Steward et al. 2005), and that attained by the CFTR anion channel with a $\mathrm{P}_{\mathrm{HCO} 3} / \mathrm{P}_{\mathrm{Cl}}$ of 0.2 is $100 \mathrm{~mm}$ (Whitcomb and Ermentrout 2004).

Recently, these limitations were complemented by a unique mode of CFTR regulation whereby the $\mathrm{P}_{\mathrm{HCO} 3} / \mathrm{P}_{\mathrm{Cl}}$ of CFTR is dynamically modulated by the $\left[\mathrm{Cl}^{-}\right]_{\mathrm{i}}$-sensitive WNK1SPAK/OSR1 kinase pathway (Park et al. 2010). In pancreatic duct cells, CFTR activation reduces $\left[\mathrm{Cl}^{-}\right]_{\mathrm{i}}$, which subsequently activates the
WNK1-SPAK/OSR1 kinase cascade. Activation of the WNK1-SPAK/OSR1 pathway significantly increases the bicarbonate permeability of CFTR, making CFTR into a bicarbonate-selective channel with a $\mathrm{P}_{\mathrm{HCO} 3} / \mathrm{P}_{\mathrm{Cl}}$ of $\sim 1.5$. This CFTR-derived bicarbonate channel would form an electrodiffusive bicarbonate efflux pathway, which can effectively generate pancreatic juice containing $>140 \mathrm{~mm}$ bicarbonate. Interestingly, SPAK and OSR1 activation simultaneously inhibits the CFTR-dependent $\mathrm{Cl}^{-} / \mathrm{HCO}_{3}^{-}$exchange activity. It is conceivable that continuous activation of apical $1 \mathrm{Cl}^{-} / 2 \mathrm{HCO}_{3}^{-}$exchange would actually absorb bicarbonate from the lumen by its reversed activity when the luminal bicarbonate concentration becomes $>128 \mathrm{~mm}$. Therefore, inhibition of the apical $\mathrm{Cl}^{-} / \mathrm{HCO}_{3}^{-}$exchange is required to prevent the reverse mode of $\mathrm{Cl}^{-} / \mathrm{HCO}_{3}^{-}$exchange activity and ultimately achieve high-bicarbonatecontaining pancreatic juice. In fact, the requirement of inhibiting the apical $\mathrm{Cl}^{-} / \mathrm{HCO}_{3}^{-}$exchange during stimulated secretion had been previously assumed by the mathematical models on high pancreatic bicarbonate secretion (Sohma et al. 2000; Steward et al. 2005).

An integrated model for pancreatic bicarbonate secretion based on the aforementioned findings is illustrated in Figure 3. In response to a meal, secretin hormone and VIP released from the vagal nerve endings stimulate pancreatic duct cells and generate cAMP signals (Lee and Muallem 2008). This initially activates bicarbonate secretion mediated by CFTR-dependent $\mathrm{Cl}^{-} / \mathrm{HCO}_{3}^{-}$exchange. The continuous increase in luminal bicarbonate and consequent reduction in luminal $\mathrm{Cl}^{-}$causes a decrease in $\left[\mathrm{Cl}^{-}\right]_{\mathrm{i}}$ to close to an electrical equilibrium (10-fold lower than luminal $\left[\mathrm{Cl}^{-}\right]$at a membrane potential of $-60 \mathrm{mV}$ ) via apical CFTR $\mathrm{Cl}^{-}$channel activity. The low $\left[\mathrm{Cl}^{-}\right]_{\mathrm{i}}$, in turn, activates WNK1 and the downstream STE20-like kinases, such as SPAK and OSR1. Activation of WNK1SPAK/OSR1 exerts two critical effects on the apical ion-transporting proteins. First, activation of WNK1-SPAK/OSR1 generates an electrogenic pathway for bicarbonate secretion by increasing the bicarbonate permeability of CFTR, which is essential for the secretion of 


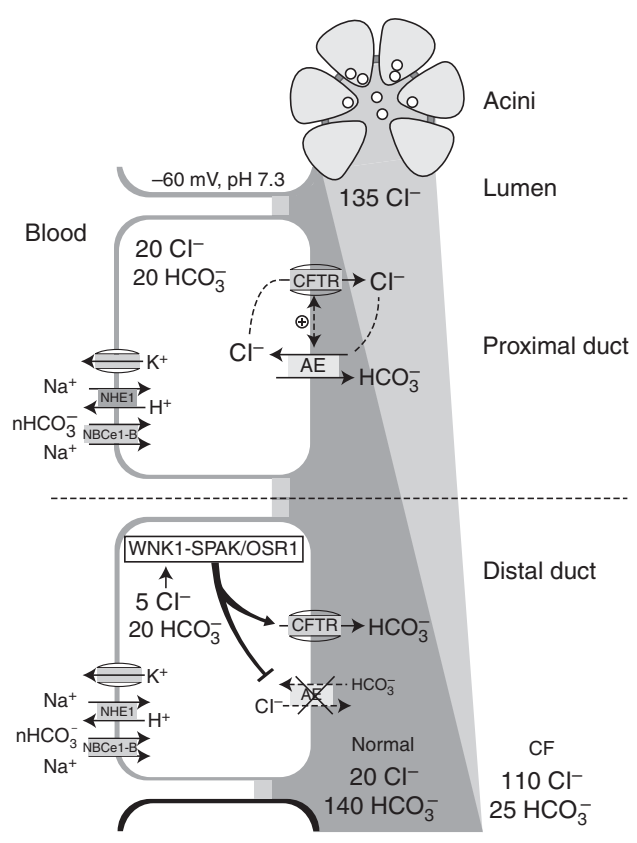

Figure 3. A model of pancreatic fluid and bicarbonate secretion. In the proximal pancreatic duct, cAMP signals activate the CFTR-dependent $\mathrm{Cl}^{-} / \mathrm{HCO}_{3}^{-}$exchange at the apical membrane, which enables the duct to absorb part of the $\mathrm{Cl}^{-}$and secrete as much as $80-100 \mathrm{~mm} \mathrm{HCO}_{3}^{-}$along with a large volume of fluid into the pancreatic juice. As the fluid arrives at the more distal portions of the duct, the reduced luminal $\mathrm{Cl}^{-}$and activated CFTR lower the intracellular $\mathrm{Cl}^{-}$concentration $\left[\mathrm{Cl}^{-}\right]_{\mathrm{i}}$ to $<10 \mathrm{~mm}$. The low $\left[\mathrm{Cl}^{-}\right]_{\mathrm{i}}$ activates WNK1, which phosphorylates SPAK/OSR1, which, in turn, acts on CFTR by converting it into a bicarbonate-selective channel. In contrast, the WNK1-SPAK/OSR1 pathway concurrently inhibits the function of apical $\mathrm{Cl}^{-} / \mathrm{HCO}_{3}^{-}$exchange to prevent bicarbonate reabsorption.

pancreatic juice containing bicarbonate at a concentration exceeding $140 \mathrm{~mm}$. Second, WNK1SPAK/OSR1 activation inhibits apical $\mathrm{Cl}^{-} /$ $\mathrm{HCO}_{3}^{-}$exchange activity that may reabsorb bicarbonate from the high-bicarbonate-containing pancreatic juice.

\section{CONCLUSION}

The model in Figure 3 describes the mechanisms underlying fluid and bicarbonate secretion in the pancreatic duct, which may also apply to other exocrine epithelia. Mechanisms of basolateral bicarbonate uptake are now relatively well established. The $\mathrm{H}^{+}$extrusion mechanisms including NHE1 expressed in the basolateral membrane of almost all epithelial cells contribute to the cellular accumulation of bicarbonate. In some cells specialized for bicarbonate secretion, such as pancreatic duct cells, NBC mediates the bulk of basolateral bicarbonate uptake. In contrast, the bicarbonate exit pathways in the apical membrane are diverse and depend on the specific condition of each type of epithelia. In epithelial cells that secrete a low concentration of bicarbonate-containing fluids (up to $80 \mathrm{~mm}$ ), either $\mathrm{Cl}^{-} / \mathrm{HCO}_{3}^{-}$exchange or CFTR anion channel with low bicarbonate permeability is sufficient to perform this task. Expression patterns of ion transporters at the apical membrane and the presence of $\mathrm{Cl}^{-}$in the lumen will determine the route of apical bicarbonate exit. In cells that secrete high-bicarbonate-containing fluids, a CFTR bicarbonate channel activity that is activated by low $\left[\mathrm{Cl}^{-}\right]_{\mathrm{i}}$ and WNK1SPAK/OSR1 kinases is required. It is important to mention that many pathological conditions in the respiratory tract and intestinal lumen can induce hypo- or hyperosmotic stress, which also activates the WNK1-SPAK/OSR1 kinases. Therefore, CFTR bicarbonate channel activity may play a role in epithelial defense against various noxious stimuli in these organs. For example, bicarbonate is an important ingredient to maintain appropriate viscosity and proper function of mucin molecules, which play a critical role in mucosal immunity and the epithelial defense system (Lee and Muallem 2008; Quinton 2008). The fact that CFTR functions not only as a $\mathrm{Cl}^{-}$channel but also a bicarbonate channel will greatly influence the arena of CFTR research and drug development toward CF patients. In addition, models of epithelial bicarbonate secretion will continue to progress as our knowledge on established pathways expands and novel mechanisms are further elucidated.

\section{ACKNOWLEDGMENTS}

We thank Dong-Su Jang for editorial assistance. M.G.L. is supported by grant 2012-0005644 from the National Research Foundation; the 
Transepithelial Bicarbonate Secretion

Ministry of Education, Science, and Technology, Korea; and grant A111218-11-PG03 from the National Project for Personalized Genomic Medicine, Korea Health 21 R\&D Project, Ministry of Health \& Welfare, Korea.

\section{REFERENCES}

Abuladze N, Lee I, Newman D, Hwang J, Boorer K, Pushkin A, Kurtz I. 1998. Molecular cloning, chromosomal localization, tissue distribution, and functional expression of the human pancreatic sodium bicarbonate cotransporter. J Biol Chem 273: 17689-17695.

Ahn W, Kim KH, Lee JA, Kim JY, Choi JY, Moe OW, Milgram SL, Muallem S, Lee MG. 2001. Regulatory interaction between the cystic fibrosis transmembrane conductance regulator and $\mathrm{HCO}_{3}^{-}$salvage mechanisms in model systems and the mouse pancreatic duct. J Biol Chem 276: 17236-17243.

Anselmo AN, Earnest S, Chen W, Juang YC, Kim SC, Zhao Y, Cobb MH. 2006. WNK1 and OSR1 regulate the $\mathrm{Na}^{+}, \mathrm{K}^{+}$, $2 \mathrm{Cl}^{-}$cotransporter in HeLa cells. Proc Natl Acad Sci 103: 10883-10888.

Argent B, Case R. 1994. Pancreatic ducts. Cellular mechanism and control of bicarbonate secretion. In Physiology of the gastrointestinal tract (ed. Johnson LR), pp. 1473-1497. Raven, New York.

Begenisich T, Nakamoto T, Ovitt CE, Nehrke K, Brugnara C, Alper SL, Melvin JE. 2004. Physiological roles of the intermediate conductance, $\mathrm{Ca}^{2+}$-activated potassium channel Kcnn4. J Biol Chem 279: 47681-47687.

Berdiev BK, Qadri YJ, Benos DJ. 2009. Assessment of the CFTR and ENaC association. Mol Biosyst 5: 123-127.

Bobulescu IA, Di Sole F, Moe OW. 2005. $\mathrm{Na}^{+} / \mathrm{H}^{+}$exchangers: Physiology and link to hypertension and organ ischemia. Curr Opin Nephrol Hypertens 14: 485-494.

Burghardt B, Elkaer ML, Kwon TH, Racz GZ, Varga G, Steward MC, Nielsen S. 2003. Distribution of aquaporin water channels AQP1 and AQP5 in the ductal system of the human pancreas. Gut 52: 1008-1016.

Caputo A, Caci E, Ferrera L, Pedemonte N, Barsanti C, Sondo E, Pfeffer U, Ravazzolo R, Zegarra-Moran O, Galietta LJ. 2008. TMEM16A, a membrane protein associated with calcium-dependent chloride channel activity. Science 322: 590-594.

Catalan MA, Nakamoto T, Gonzalez-Begne M, Camden JM, Wall SM, Clarke LL, Melvin JE. 2010. Cftr and ENaC ion channels mediate $\mathrm{NaCl}$ absorption in the mouse submandibular gland. J Physiol 588: 713-724.

Cook DI, Dinudom A, Komwatana P, Kumar S, Young JA. 2002. Patch-clamp studies on epithelial sodium channels in salivary duct cells. Cell Biochem Biophys 36: 105-113.

Deeley RG, Westlake C, Cole SP. 2006. Transmembrane transport of endo- and xenobiotics by mammalian ATP-binding cassette multidrug resistance proteins. Physiol Rev 86: 849-899.

Delporte C, Steinfeld S. 2006. Distribution and roles of aquaporins in salivary glands. Biochim Biophys Acta 1758: $1061-1070$.
Domschke S, Domschke W, Rosch W, Konturek SJ, Sprugel W, Mitznegg P, Wunsch E, Demling L. 1977. Inhibition by somatostatin of secretin-stimulated pancreatic secretion in man: A study with pure pancreatic juice. Scand J Gastroenterol 12: 59-63.

Dorwart MR, Shcheynikov N, Yang D, Muallem S. 2008. The solute carrier 26 family of proteins in epithelial ion transport. Physiology (Bethesda) 23: 104-114.

Dyck WP, Hightower NC, Janowitz HD. 1972. Effect of acetazolamide on human pancreatic secretion. Gastroenterology 62: 547-552.

Gee HY, Kim YW, Jo MJ, Namkung W, Kim JY, Park HW, Kim KS, Kim H, Baba A, Yang J, et al. 2009. Synaptic scaffolding molecule binds to and regulates vasoactive intestinal polypeptide type-1 receptor in epithelial cells. Gastroenterology 137: 607-617.

Gerolami A, Marteau C, Matteo A, Sahel J, Portugal H, Pauli AM, Pastor J, Sarles H. 1989. Calcium carbonate saturation in human pancreatic juice: Possible role of ductal $\mathrm{H}^{+}$ secretion. Gastroenterology 96: 881-884.

Gray MA, Harris A, Coleman L, Greenwell JR, Argent BE. 1989. Two types of chloride channel on duct cells cultured from human fetal pancreas. Am J Physiol 257: C240-C251.

Gray MA, Greenwell JR, Garton AJ, Argent BE. 1990. Regulation of maxi- $\mathrm{K}^{+}$channels on pancreatic duct cells by cyclic AMP-dependent phosphorylation. J Membr Biol 115: 203-215.

Gray MA, Winpenny JP, Porteous DJ, Dorin JR, Argent BE. 1994. CFTR and calcium-activated chloride currents in pancreatic duct cells of a transgenic CF mouse. Am J Physiol 266: C213-C221.

Gross E, Fedotoff O, Pushkin A, Abuladze N, Newman D, Kurtz I. 2003. Phosphorylation-induced modulation of pNBC1 function: Distinct roles for the amino- and carboxy-termini. J Physiol 549: 673-682.

Guggino WB. 2004. The cystic fibrosis transmembrane regulator forms macromolecular complexes with PDZ domain scaffold proteins. Proc Am Thorac Soc 1: 28-32.

Han W, Kim KH, Jo MJ, Lee JH, Yang J, Doctor RB, Moe OW, Lee J, Kim E, Lee MG. 2006. Shank2 associates with and regulates $\mathrm{Na}^{+} / \mathrm{H}^{+}$exchanger 3. J Biol Chem 281: $1461-$ 1469.

Hatefi Y, Hanstein WG. 1969. Solubilization of particulate proteins and nonelectrolytes by chaotropic agents. Proc Natl Acad Sci 62: 1129-1136.

Hayashi T, Young JA, Cook DI. 1996. The Ach-evoked Ca ${ }^{2+}$. activated $\mathrm{K}^{+}$current in mouse mandibular secretory cells. Single channel studies. J Membr Biol 151: 19-27.

Hayashi M, Kunii C, Takahata T, Ishikawa T. 2004. ATPdependent regulation of SK4/IK1-like currents in rat submandibular acinar cells: Possible role of cAMP-dependent protein kinase. Am J Physiol Cell Physiol 286: C635-C646.

Huang F, Rock JR, Harfe BD, Cheng T, Huang X, Jan YN, Jan LY. 2009. Studies on expression and function of the TMEM16A calcium-activated chloride channel. Proc Natl Acad Sci 106: 21413-21418.

Ishiguro H, Steward MC, Lindsay AR, Case RM. 1996a. Accumulation of intracellular $\mathrm{HCO}_{3}^{-}$by $\mathrm{Na}^{+}-\mathrm{HCO}_{3}^{-}$ 
H.W. Park and M.G. Lee

cotransport in interlobular ducts from guinea-pig pancreas. J Physiol 495: 169-178.

Ishiguro H, Steward MC, Wilson RW, Case RM. 1996b. Bicarbonate secretion in interlobular ducts from guinea-pig pancreas. J Physiol 495: 179-191.

Ishiguro H, Naruse S, Steward MC, Kitagawa M, Ko SB, Hayakawa T, Case RM. 1998. Fluid secretion in interlobular ducts isolated from guinea-pig pancreas. J Physiol 511: 407-422.

Ishiguro H, Naruse S, Kitagawa M, Mabuchi T, Kondo T, Hayakawa T, Case RM, Steward MC. 2002. Chloride transport in microperfused interlobular ducts isolated from guinea-pig pancreas. J Physiol 539: 175-189.

Ishiguro H, Steward MC, Naruse S, Ko SB, Goto H, Case RM, Kondo T, Yamamoto A. 2009. CFTR functions as a bicarbonate channel in pancreatic duct cells. J Gen Physio 133: 315-326.

Johansen PG, Anderson CM, Hadorn B. 1968. Cystic fibrosis of the pancreas. A generalised disturbance of water and electrolyte movement in exocrine tissues. Lancet 1: 455-460.

Kerem B, Rommens JM, Buchanan JA, Markiewicz D, Cox TK, Chakravarti A, Buchwald M, Tsui LC. 1989. Identification of the cystic fibrosis gene: Genetic analysis. Science 245: 1073-1080.

Kim JY, Han W, Namkung W, Lee JH, Kim KH, Shin H, Kim E, Lee MG. 2004. Inhibitory regulation of cystic fibrosis transmembrane conductance regulator anion-transporting activities by Shank2. J Biol Chem 279: 10389-10396.

Ko SB, Shcheynikov N, Choi JY, Luo X, Ishibashi K, Thomas PJ, Kim JY, Kim KH, Lee MG, Naruse S, et al. 2002. A molecular mechanism for aberrant CFTR-dependent $\mathrm{HCO}_{3}^{-}$transport in cystic fibrosis. EMBO J 21: 5662 5672.

Ko SB, Zeng W, Dorwart MR, Luo X, Kim KH, Millen L, Goto H, Naruse S, Soyombo A, Thomas PJ, et al. 2004. Gating of CFTR by the STAS domain of SLC26 transporters. Nat Cell Biol 6: 343-350.

Kunzelmann K. 2001. CFTR: Interacting with everything? News Physiol Sci 16: 167-170.

Kunzelmann K, Kongsuphol P, Aldehni F, Tian Y, Ousingsawat J, Warth R, Schreiber R. 2009. Bestrophin and TMEM16-Ca ${ }^{2+}$ activated $\mathrm{Cl}^{-}$channels with different functions. Cell Calcium 46: 233-241.

Lee MG, Muallem S. 2008. Physiology of duct cell secretion. In Pancreas: An integrated textbook of basic science, medicine, and surgery (ed. Beger $\mathrm{H}$, et al.), pp. 78-90. Blackwell, Oxford.

Lee MG, Choi JY, Luo X, Strickland E, Thomas PJ, Muallem S. 1999a. Cystic fibrosis transmembrane conductance regulator regulates luminal $\mathrm{Cl}^{-} / \mathrm{HCO}_{3}^{-}$exchange in mouse submandibular and pancreatic ducts. J Biol Chem 274: 14670-14677.

Lee MG, Wigley WC, Zeng W, Noel LE, Marino CR, Thomas PJ, Muallem S. 1999b. Regulation of $\mathrm{Cl}^{-} / \mathrm{HCO}_{3}^{-}$exchange by cystic fibrosis transmembrane conductance regulator expressed in NIH 3T3 and HEK 293 cells. J Biol Chem 274: 3414-3421.

Lee MG, Ahn W, Choi JY, Luo X, Seo JT, Schultheis PJ, Shull GE, Kim KH, Muallem S. 2000. $\mathrm{Na}^{+}$-dependent transporters mediate $\mathrm{HCO}_{3}^{-}$salvage across the luminal mem- brane of the main pancreatic duct. J Clin Invest 105: 1651-1658.

Lee JH, Richter W, Namkung W, Kim KH, Kim E, Conti M, Lee MG. 2007. Dynamic regulation of cystic fibrosis transmembrane conductance regulator by competitive interactions of molecular adaptors. J Biol Chem 282: 10414-10422.

Lee MG, Ohana E, Park HW, Yang D, Muallem S. 2012. Molecular mechanism of pancreatic and salivary gland fluid and $\mathrm{HCO}_{3}^{-}$secretion. Physiol Rev 92: 39-74.

Linsdell P, Tabcharani JA, Rommens JM, Hou YX, Chang XB, Tsui LC, Riordan JR, Hanrahan JW. 1997. Permeability of wild-type and mutant cystic fibrosis transmembrane conductance regulator chloride channels to polyatomic anions. J Gen Physiol 110: 355-364.

Luo X, Choi JY, Ko SB, Pushkin A, Kurtz I, Ahn W, Lee MG, Muallem S. 2001. $\mathrm{HCO}_{3}^{-}$salvage mechanisms in the submandibular gland acinar and duct cells. J Biol Chem 276: 9808-9816.

Marteau C, Blanc G, Devaux MA, Portugal H, Gerolami A. 1993. Influence of pancreatic ducts on saturation of juice with calcium carbonate in dogs. Dig Dis Sci 38: 2090 2097.

Marteau C, Silviani V, Ducroc R, Crotte C, Gerolami A. 1995. Evidence for apical $\mathrm{Na}^{+} / \mathrm{H}^{+}$exchanger in bovine main pancreatic duct. Dig Dis Sci 40: 2336-2340.

Maruyama Y, Petersen OH, Flanagan P, Pearson GT. 1983. Quantification of $\mathrm{Ca}^{2+}$-activated $\mathrm{K}^{+}$channels under hormonal control in pig pancreas acinar cells. Nature 305: $228-232$.

McMurtrie HL, Cleary HJ, Alvarez BV, Loiselle FB, Sterling D, Morgan PE, Johnson DE, Casey JR. 2004. The bicarbonate transport metabolon. J Enzyme Inhib Med Chem 19: $231-236$.

Melvin JE, Yule D, Shuttleworth T, Begenisich T. 2005. Regulation of fluid and electrolyte secretion in salivary gland acinar cells. Annu Rev Physiol 67: 445-469.

Morth JP, Pedersen BP, Buch-Pedersen MJ, Andersen JP, Vilsen B, Palmgren MG, Nissen P. 2011. A structural overview of the plasma membrane $\mathrm{Na}^{+}, \mathrm{K}^{+}$-ATPase and $\mathrm{H}^{+}$-ATPase ion pumps. Nat Rev Mol Cell Biol 12: 60-70.

Nakamoto T, Romanenko VG, Takahashi A, Begenisich T, Melvin JE. 2008. Apical maxi-K (KCa1.1) channels mediate $\mathrm{K}^{+}$secretion by the mouse submandibular exocrine gland. Am J Physiol Cell Physiol 294: C810-C819.

Nehrke K, Quinn CC, Begenisich T. 2003. Molecular identification of $\mathrm{Ca}^{2+}$-activated $\mathrm{K}^{+}$channels in parotid acinar cells. Am J Physiol Cell Physiol 284: C535-C546.

Novak I, Greger R. 1988. Electrophysiological study of transport systems in isolated perfused pancreatic ducts: Properties of the basolateral membrane. Pflugers Arch 411: $58-68$.

Novak I, Wang J, Henriksen KL, Haanes KA, Krabbe S, Nitschke R, Hede SE. 2011. Pancreatic bicarbonate secretion involves two proton pumps. J Biol Chem 286: $280-$ 289.

Ohana E, Yang D, Shcheynikov N, Muallem S. 2009. Diverse transport modes by the solute carrier 26 family of anion transporters. J Physiol 587: 2179-2185. 
Olsnes S, Tonnessen TI, Sandvig K. 1986. pH-regulated anion antiport in nucleated mammalian cells. J Cell Bio 102: $967-971$.

O'Reilly CM, Winpenny JP, Argent BE, Gray MA. 2000. Cystic fibrosis transmembrane conductance regulator currents in guinea pig pancreatic duct cells: Inhibition by bicarbonate ions. Gastroenterology 118: 1187-1196.

Pak BH, Hong SS, Pak HK, Hong SK. 1966. Effects of acetazolamide and acid-base changes on biliary and pancreatic secretion. Am J Physiol 210: 624-628.

Park K, Olschowka JA, Richardson LA, Bookstein C, Chang EB, Melvin JE. 1999. Expression of multiple $\mathrm{Na}^{+} / \mathrm{H}^{+}$ exchanger isoforms in rat parotid acinar and ductal cells. Am J Physiol 276: G470-G478.

Park M, Ko SB, Choi JY, Muallem G, Thomas PJ, Pushkin A, Lee MS, Kim JY, Lee MG, Muallem S, et al. 2002. The cystic fibrosis transmembrane conductance regulator interacts with and regulates the activity of the $\mathrm{HCO}_{3}^{-}$salvage transporter human $\mathrm{Na}^{+}-\mathrm{HCO}_{3}^{-}$cotransport isoform 3. J Biol Chem 277: 50503-50509.

Park HW, Nam JH, Kim JY, Namkung W, Yoon JS, Lee JS, Kim KS, Venglovecz V, Gray MA, Kim KH, et al. 2010. Dynamic regulation of CFTR bicarbonate permeability by $\left[\mathrm{Cl}^{-}\right]_{\mathrm{i}}$ and its role in pancreatic bicarbonate secretion. Gastroenterology 139: 620-631.

Poulsen JH, Fischer H, Illek B, Machen TE. 1994. Bicarbonate conductance and $\mathrm{pH}$ regulatory capability of cystic fibrosis transmembrane conductance regulator. Proc Natl Acad Sci 91: 5340-5344.

Quinton PM. 2001. The neglected ion: $\mathrm{HCO}_{3}^{-}$. Nat Med 7: 292-293.

Quinton PM. 2008. Cystic fibrosis: Impaired bicarbonate secretion and mucoviscidosis. Lancet 372: 415-417.

Quinton PM. 2010. Role of epithelial $\mathrm{HCO}_{3}$ transport in mucin secretion: Lessons from cystic fibrosis. Am J Physiol Cell Physiol 299: C1222-C1233.

Reddy MM, Quinton PM. 2003. Control of dynamic CFTR selectivity by glutamate and ATP in epithelial cells. $\mathrm{Na}$ ture 423: 756-760.

Reddy MM, Light MJ, Quinton PM. 1999. Activation of the epithelial $\mathrm{Na}^{+}$channel $(\mathrm{ENaC})$ requires $\mathrm{CFTR} \mathrm{Cl}^{-}$channel function. Nature 402: 301-304.

Richardson C, Alessi DR. 2008. The regulation of salt transport and blood pressure by the WNK-SPAK/OSR1 signalling pathway. J Cell Sci 121: 3293-3304.

Romanenko V, Nakamoto T, Srivastava A, Melvin JE, Begenisich T. 2006. Molecular identification and physiological roles of parotid acinar cell maxi-K channels. J Biol Chem 281: 27964-27972.

Romanenko VG, Catalan MA, Brown DA, Putzier I, Hartzell HC, Marmorstein AD, Gonzalez-Begne M, Rock JR, Harfe BD, Melvin JE. 2010. Tmem16A encodes the $\mathrm{Ca}^{2+}$-activated $\mathrm{Cl}^{-}$channel in mouse submandibular salivary gland acinar cells. J Biol Chem 285: $12990-$ 13001.

Roos A, Boron WF. 1981. Intracellular pH. Physiol Rev 61: 296-434.

Roussa E, Romero MF, Schmitt BM, Boron WF, Alper SL, Thevenod F. 1999. Immunolocalization of anion exchanger $\mathrm{AE} 2$ and $\mathrm{Na}^{+}-\mathrm{HCO}_{3}^{-}$cotransporter in rat parot- id and submandibular glands. Am J Physiol 277: G1288-G1296.

Roussa E, Alper SL, Thevenod F. 2001. Immunolocalization of anion exchanger AE2, $\mathrm{Na}^{+} / \mathrm{H}^{+}$exchangers NHE1 and NHE4, and vacuolar type $\mathrm{H}^{+}$-ATPase in rat pancreas. J Histochem Cytochem 49: 463-474.

Schroeder BC, Cheng T, Jan YN, Jan LY. 2008. Expression cloning of TMEM16A as a calcium-activated chloride channel subunit. Cell 134: 1019-1029.

Shcheynikov N, Kim KH, Kim KM, Dorwart MR, Ko SB, Goto H, Naruse S, Thomas PJ, Muallem S. 2004. Dynamic control of cystic fibrosis transmembrane conductance regulator $\mathrm{Cl}^{-} / \mathrm{HCO}_{3}^{-}$selectivity by external $\mathrm{Cl}^{-}$. J Biol Chem 279: 21857-21865.

Shcheynikov N, Yang D, Wang Y, Zeng W, Karniski LP, So I, Wall SM, Muallem S. 2008. The Slc26a4 transporter functions as an electroneutral $\mathrm{Cl}^{-} / \mathrm{I}^{-} / \mathrm{HCO}_{3}^{-}$exchanger: Role of Slc26a4 and Slc26a6 in $\mathrm{I}^{-}$and $\mathrm{HCO}_{3}^{-}$secretion and in regulation of CFTR in the parotid duct. J Physiol 586: $3813-3824$.

Shirakabe K, Priori G, Yamada H, Ando H, Horita S, Fujita T, Fujimoto I, Mizutani A, Seki G, Mikoshiba K. 2006. IRBIT, an inositol 1,4,5-trisphosphate receptor-binding protein, specifically binds to and activates pancreas-type $\mathrm{Na}^{+} / \mathrm{HCO}_{3}^{-}$cotransporter 1 (pNBC1). Proc Natl Acad Sci 103: 9542-9547.

Short DB, Trotter KW, Reczek D, Kreda SM, Bretscher A, Boucher RC, Stutts MJ, Milgram SL. 1998. An apical PDZ protein anchors the cystic fibrosis transmembrane conductance regulator to the cytoskeleton. J Biol Chem 273: 19797-19801.

Sohma Y, Gray MA, Imai Y, Argent BE. 1996. A mathematical model of the pancreatic ductal epithelium. J Membr Biol 154: 53-67.

Sohma Y, Gray MA, Imai Y, Argent BE. 2000. $\mathrm{HCO}_{3}^{-}$transport in a mathematical model of the pancreatic ductal epithelium. J Membr Biol 176: 77-100.

Stephan AB, Shum EY, Hirsh S, Cygnar KD, Reisert J, Zhao H. 2009. ANO2 is the cilial calcium-activated chloride channel that may mediate olfactory amplification. Proc Natl Acad Sci 106: 11776-11781.

Steward MC, Ishiguro H, Case RM. 2005. Mechanisms of bicarbonate secretion in the pancreatic duct. Annu Rev Physiol 67: 377-409.

Stewart AK, Yamamoto A, Nakakuki M, Kondo T, Alper SL, Ishiguro H. 2009. Functional coupling of apical $\mathrm{Cl}^{-} /$ $\mathrm{HCO}_{3}^{-}$exchange with CFTR in stimulated $\mathrm{HCO}_{3}^{-}$secretion by guinea pig interlobular pancreatic duct. Am J Physiol Gastrointest Liver Physiol 296: G1307-G1317.

Tabcharani JA, Chang XB, Riordan JR, Hanrahan JW. 1991. Phosphorylation-regulated $\mathrm{Cl}^{-}$channel in $\mathrm{CHO}$ cells stably expressing the cystic fibrosis gene. Nature 352: $628-631$.

Venglovecz V, Rakonczay Z Jr, Ozsvari B, Takacs T, Lonovics J, Varro A, Gray MA, Argent BE, Hegyi P. 2008. Effects of bile acids on pancreatic ductal bicarbonate secretion in guinea pig. Gut 57: 1102-1112.

Venglovecz V, Hegyi P, Rakonczay Z Jr, Tiszlavicz L, Nardi A, Grunnet M, Gray MA. 2011. Pathophysiological relevance of apical large-conductance $\mathrm{Ca}^{2+}$-activated potassium channels in pancreatic duct epithelial cells. Gut 60: 361-369. 
H.W. Park and M.G. Lee

Verkman AS. 2008. Mammalian aquaporins: Diverse physiological roles and potential clinical significance. Expert Rev Mol Med 10: e13.

Villanger O, Veel T, Raeder MG. 1995. Secretin causes $\mathrm{H}^{+} /$ $\mathrm{HCO}_{3}^{-}$secretion from pig pancreatic ductules by vacuolar-type $\mathrm{H}^{+}$-adenosine triphosphatase. Gastroenterology 108: $850-859$.

Wang S, Raab RW, Schatz PJ, Guggino WB, Li M. 1998. Peptide binding consensus of the NHE-RF-PDZ1 domain matches the $\mathrm{C}$-terminal sequence of cystic fibrosis transmembrane conductance regulator (CFTR). FEBS Lett 427: 103-108.

Wang Y, Soyombo AA, Shcheynikov N, Zeng W, Dorwart M, Marino CR, Thomas PJ, Muallem S. 2006. Slc26a6 regulates CFTR activity in vivo to determine pancreatic duct $\mathrm{HCO}_{3}^{-}$secretion: Relevance to cystic fibrosis. EMBO J 25: 5049-5057.

Whitcomb DC, Ermentrout GB. 2004. A mathematical model of the pancreatic duct cell generating high bicarbonate concentrations in pancreatic juice. Pancreas 29: e30-e40.
Xie Q, Welch R, Mercado A, Romero MF, Mount DB. 2002. Molecular characterization of the murine Slc26a6 anion exchanger: Functional comparison with Slc26a1. Am J Physiol Renal Physiol 283: F826-F838.

Yang YD, Cho H, Koo JY, Tak MH, Cho Y, Shim WS, Park SP, Lee J, Lee B, Kim BM, et al. 2008. TMEM16A confers receptor-activated calcium-dependent chloride conductance. Nature 455: 1210-1215.

Zeng W, Lee MG, Muallem S. 1997. Membrane-specific regulation of $\mathrm{Cl}^{-}$channels by purinergic receptors in rat submandibular gland acinar and duct cells. J Biol Chem 272: 32956-32965.

Zhao H, Star RA, Muallem S. 1994. Membrane localization of $\mathrm{H}^{+}$and $\mathrm{HCO}_{3}^{-}$transporters in the rat pancreatic duct. J Gen Physiol 104: 57-85.

Zsembery A, Strazzabosco M, Graf J. 2000. $\mathrm{Ca}^{2+}$-activated $\mathrm{Cl}^{-}$channels can substitute for CFTR in stimulation of pancreatic duct bicarbonate secretion. FASEB J 14: 2345-2356. 


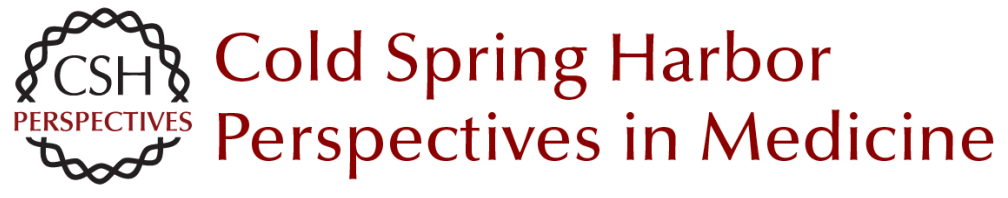

\section{Transepithelial Bicarbonate Secretion: Lessons from the Pancreas}

Hyun Woo Park and Min Goo Lee

Cold Spring Harb Perspect Med 2012; doi: 10.1101/cshperspect.a009571

Subject Collection Cystic Fibrosis

Antibiotic and Anti-Inflammatory Therapies for

Cystic Fibrosis

James F. Chmiel, Michael W. Konstan and J. Stuart Elborn

Structure and Function of the Mucus Clearance System of the Lung

Brenda M. Button and Brian Button

New Pulmonary Therapies Directed at Targets

Other than CFTR

Scott H. Donaldson and Luis Galietta

The Cystic Fibrosis Airway Microbiome

Susan V. Lynch and Kenneth D. Bruce

Cystic Fibrosis Transmembrane Conductance

Regulator (ABCC7) Structure

John F. Hunt, Chi Wang and Robert C. Ford

Status of Fluid and Electrolyte Absorption in

Cystic Fibrosis

M.M. Reddy and M. Jackson Stutts

The Influence of Genetics on Cystic Fibrosis

Phenotypes

Michael R. Knowles and Mitchell Drumm

Perspectives on Mucus Properties and Formation

--Lessons from the Biochemical World

Daniel Ambort, Malin E.V. Johansson, Jenny K.

Gustafsson, et al.
The Cystic Fibrosis Intestine

Robert C. De Lisle and Drucy Borowitz

Cystic Fibrosis Transmembrane Regulator

Correctors and Potentiators

Steven M. Rowe and Alan S. Verkman

The Cystic Fibrosis of Exocrine Pancreas

Michael Wilschanski and Ivana Novak

Dynamics Intrinsic to Cystic Fibrosis

Transmembrane Conductance Regulator Function and Stability

P. Andrew Chong, Pradeep Kota, Nikolay V.

Dokholyan, et al.

The Cystic Fibrosis Gene: A Molecular Genetic

Perspective

Lap-Chee Tsui and Ruslan Dorfman

The CFTR Ion Channel: Gating, Regulation, and

Anion Permeation

Tzyh-Chang Hwang and Kevin L. Kirk

Assessing the Disease-Liability of Mutations in CFTR

Claude Ferec and Garry R. Cutting

Supramolecular Dynamics of Mucus Pedro Verdugo

For additional articles in this collection, see http://perspectivesinmedicine.cshlp.org/cgi/collection/ 